\title{
IDEOLOGI NYEGARA GUNUNG: SEBUAH KAJIAN SOSIOKULTURAL KEMISKINAN PADA MASYARAKAT PESISIR DI BALI UTARA
}

\author{
I Wayan Mudana \\ Jurusan Pendidikan Sejarah, Fakultas IImu Sosial, Universitas Pendidikan Ganesha \\ Singaraja, Indonesia
}

\begin{abstract}
Abstrak
Target khusus yang ingin dicapai dalam tahun ini adalah terdeskrepsikannya fenomenan kemiskinan sosiokultural dan geneologis kemiskinan sosiokultural masyarakat pesisir; terdeskrepsikannya secara kritis ideologi nyegara gunung yang berkembang pada masyarakat pesisir; terdeskrepsikannya secara kritis keberfungsian ideologi nyegara gunung dalam mengatasi masalah kemiskinan sosiokultural pada masyarakat pesisir di Bali Utara; serta tersdeskrepsikannya peranan masyarakat politik, ekonomi dan sipil dalam pengentasan kemiskinan sosiokultural berbasis ideologi nyegara gunung pada masyarakat prsisir di Bali Utara. Pendekatan yang digunakan dalam penelitian ini pada tahun pertama adalah pendekatan yang bersifat etnografis kritis. Sehunbungan dengan hal itu, informan penelitian ini menggunakan purposive smowball, pengumpulan data dengan observasi, wawancara mendalam, dan studi pustaka, analisis data menggunakan analisis kritis deskreptif kualitatif.

Berdasarkan pendekatan tersebut di atas dapat dikemukakan hasil kajian ini sebagai berikut: Kemiskinan sosiokultural masyarakat di Bali Utara dapat dilihat dari lingkungan pemukiman masyarakat pesisir yang berada di sekitar pantai pada umumnya menempati tanah negara dan dengan kondisi bangunan yang sangat sederhana. Kemiskinan sosiokultural yang dimilikinya juga tercermin oleh tingkat pendidikan dan penguasan teknologi kebaharian yang masih terbatasa. Kondisi ini tentu saja juga terkait dengan keterbatasan modal finansial yang dimiliki oleh $\mathrm{m}$ syarakat pesisir.Terjadinya kemiskinan sosiokultural pada masyarakat pesisir secara geneologis disebabkan oleh keterbatasan modal financial yang dimiliki dan kebijakan-kebijakan pembangunan yang kurang berpihak pada masyarakat pesisir yang mengalami jeratan gurita kemiskinan. Dalam mengatasi kemiskinan sosiokultural, masyarakat pesisir mengembangkan berbagai aktivitas sosial ekonomi yang dilandasi kesadarannya terhadap kebenaran ideologi nyegara gunung, dan menjadikan laut sebagai ruang hidup yang menjanjikan. Di samping itu, masyarakat pesisir juga mengembangkan berbagai diversifikasi usaha dan kelembagaan kredit sosial dan ekonomi sebagai bentuk adaptasinya dalam mengatasi kemiskinan sosiokultural yang ada. Dalam mengatasi kemiskinan, masyarakat politik, ekonomi dan sipil ikut berperan, baik dalam bentuk pendampingan modal maupun pembinaan terhadap masyarakat pesisir.
\end{abstract}

Kata Kunci: nyegara gunung,kemiskinan, sosikultural.

\begin{abstract}
Special target that will be reached out in this year, the phenomena description of sociocultural poverty and genealogy of sociocultural poverty at shore community; The critical ideology description of nyegara gunung, that develop at shore community; The critical description, the function of nyegara gunung ideology in protecting the problem of sociocultural poverty at shore community in north Bali; Description the role of political community, economy and civil in raising the sociocultural poverty that bases nyegara gunung ideology at shore community in north Bali.The approach usung in this study at the first year is approach that has critical ethnography character. According to the matter, the informant in this study uses snowball purposive, collecting of data by observation, deep interview and document study, analyze of data use critical analysis qualitative description.
\end{abstract}


By the approach written in this report can be explained, the result of this analysis as follow: The poverty of sociocultural at the shore community in north Bali can be seen from settlement environment at shore community that live arround the shore. In generally, they occupy the land belong to government, and in a building with very simple condition. The sociocultural poverty that belongs to them, is decribed by educational level and mastery of mariteme technology that is still lax. That condition in fact, connect with limitation of finnancial capital, belongs to the shore community. The sociocultural poverty has happened at shore community in genealogical way is caused by limitation of finnancial capital that belongs to them, and the building wisdom dosn't take sides to the shore community that has been handcuffed by poverty. In controlling the sociocultural poverty, shore community develops some activities of economic social, that's based by awareness to the truth of nyegara gunung ideology, and making the sea as life space that has a potencial enough. On the other way, shore community also develop some deversification of efforts and cridit organazation of economic social as a shape of adaptation in surpassing the sociocultural poverty. In surpassing the poverty, polotic community, economy \& civil have roled, either in capital closeness model, or founding to the shore community.

Key words: nyegara gunung, poverty, sociocultural

\section{PENDAHULUAN}

Daerah Bali cenderung diidentikkan dengan daerah agraris dan daerah pariwisata. Padahal ada sebagian masyarakatnya yang menekuni kegiatan sebagai kemaritiman, dalam hal ini masyarakat pesisir, yang pada umumnya tidak saja mengalami kemiskinan finansial, tetapi juga mengalami kemiskinan sosiokultural. Berkenaan dengan hal itu maka kajian terhadap masyarakat pesisir di Bali Utara amatlah penting, khususnya dalam perspektif ideologi nyegara gunung. Kajian terhadap hal tersebut didasarkan atas hasil studi pendahuluan baik melalui studi karya tesis yaitu tentang Kredit Sosial dan Kredit Ekonomi pada Masyarakat Nelayan di Desa Kubutambahan (Mudana, 2001), maupun melalui kajian penelitian dosen muda tentang Kekuatan Religius Magis Dalam Proses Eksploitasi Sumber Daya Kelautan Pada Masyarakat Nelayan di Bali Utara, (Mudana, 2003), dan melalui penelitian kajian wanita tentang Etos Kerja Nelayan dan Implikasinya terhadap Kehidupan Ekonomi Keluarga Masyarakat Nelayan di Desa Kubutambahan (Mudjiono dan Mudana, 2003). Melalui hal itu terlihat ada kekuatan ideologis nyegara gunung yang dapat dijadikan sebagai suatu basis dalam membebaskan masyarakat pesisir dari belenggu kemiskinan sosiokultural.

\begin{abstract}
Pentingnya kajian ini juga karena selama ini kajian-kajian terhadap masyarakat pesisir belum ada yang mengkaji secara khusus tentang ideologi nyegara gunung dalam pembebasan masyarakat pesisir dari belenggu kemiskinan sosiokultural di Bali Utara. Kalaupun ada ideologi nyegara gunung hanya diposisikan sebagai ideologi yamg terkait dengan aktivitas religius magis, padahal ideologi nyegara gunung tidak hanya berdimensi sosioreligius magis, tetapi juga sosiokultural, sosial ekonomi, dan ekologis (ruang hidup), sehingga dapat berkontribusi dalam mengatasi masalah kemiskinan sosiokultural, keretakan sosial, maupun kerusakan lingkungan pada masyarakat pesisir. Hal mana sejalan dengan paradigma pembangunan berkelanjutan.

Pengkajian kemiskinan sosiokultural berbasis ideologi nyegara gunung dalam perspektif sosiokultural tidak saja memiliki kebermanfaatan secara akademis, sebagai pengayaan materi bahan ajar dalam pembelajaran Sosiologi-Antropologi Pembangunan, memperkuat penggugatan terhadap teori pembangunan modernis, tetapi juga memiliki manfaat praktis dalam memecahkan masalah sosial ekonomi, kultural dan lingkungan.
\end{abstract}


Kajian ini juga terkait dengan kapasitas manusia sebagai makhluk ekologis, sehubungan dengan hal itu dikembangkanlah etika lingkungan yang didasarkan atas kesetaraan, tanggung jawab, kepedulian, dan kasih sayang Kesadaran semacam itu merupakan konskwensi logis dari keberadaan manusia dibentuk oleh dan merealisasikan dirinya dalam alam. Alam membentuk dirinya sebagaimana ia sendiri ikut membentuk alam (Kraf, 2002:xvii-xix; Sumaatmadja, 2000:73 Mubyarto,dkk, 1992:43). Prinsip ekologis itu pada dasarnya saling ketergantungan, kemitraan, dan bersifat siklis. Prinsip ekologis semacam itu tampaknya telah menjadi pandangan moral pada masyarakat adat. Di dalamnya, terkandung keyakinan moral religius. (Keraf, 2002: 283). Secara umum etika lingkungan masyarakat Bali dilandasi oleh ajaran tri hita karana (Prime, 2006). Menurut Eisman (1982:2) tri hita karana pada hakikatnya tidak hanya merupakan citra lingkungan, tetapi juga cosmologi dan ideologi bagi masyarakat Bali. Karena gagasan, ide-ide yang terkandung di dalamnya akan terefleksikan dalam berbagai pola perilaku masyarakat Bali, baik dalam kaitannya perilaku dalam hubungan manusia dengan Tuhan yang Maha Esa, perilaku dalam hubungan manusia dengan manusia, maupun perilaku dalam hubungan manusia dengan alam semesta. Hal ini akan semakin jelas bila dilihat dari cara pandang sistemik.

Keberadaan ajaran tri hita karana semakin mantap dengan adanya agama Hindu sebagai landasan moralnya. Fenomena ini merupakan hal yang paling fundamental dari etika lingkungan yang memandang dirinya, alam dan relasi di antara keduannya dalam perspektif perspektif spiritual. Maka, alam dipahami oleh semua masyarakat tradisional sebagai sesuatu yang sakral, kudus. Dalam konteks masyarakat Bali, hal itu sejalan dengan pandangan masyarakat Bali yang memandang bahwa tatanan kosmis dipandang bersifat sekala dan niskala
(Mudana, 2001:138). Pemahaman seperti itu juga akan selalu menjiwai, mewarnai dan menandai setiap aktivitas manusia (Kraf, 2002:282). Pemahaman tersebut akan semakin kuat dengan adanya berbagai pranata-pranata keagamaan, seperti: pura, sistem ritual, dan kelembagaan keagamaan PHDI yang tidak saja berperan sebagai kelembagaan sosialisasi, tetapi juga sebagai kelembagaan kontro (Wiana, 2006:12; Susilo, 2003: 87). Terpeliharanya keseimbangan sistem atau homeostatis merupakan kekuatan pengatur' perimbangan alam' atau the balance of nature (Poerwanto, 2000, 65). Dalam tataran semiotika hal itu semua pada dasarnya merupakan suatu teks, khususnya teks kognetif. Teks kognetif semavcam itu merupakan modal kultural yang dapat berkontribusi dalam mengatasi kemiskinan atau membebaskan masyarakat pesisir dari belenggu kemiskinan sosiokultural..

Adapun rumusan masalah penelitian ini adalah sebagai berikut:

1 Bagaimana fenomena kemiskinan sosiokultural pada masyarkat pesisir di Bali Utara?

2 Bagaimana geneologis kemiskinan sosiokultural masyarakat pesisir?

3 Bagaimana ideologi nyegara gunung yang berkembang pada masyarakat pesisir di Bali Utara?

4 Bagaimana keberfungsian ideologi nyegara gunung dalam mengatasi masalah kemiskinan sosiokultural pada masyarakat pesisir di Bali Utara?

\section{METODE}

Pendekatan yang digunakan dalam penelitian ini pada tahun pertama adalah pendekatan yang bersifat etnografis kritis. Sehunbungan dengan hal itu maka informan penelitian ini adalah masyarakat pesisir yang ada di wilayah Desa Pemuteran, Kalibukbuk, dan Les. Penentuan informan menggunakan purposive smowball. Pengumpulan data tentang fenemomena kemiskinan dilakukan dengan observasi, 
studi pustaka dan wawancara mendalam. Pengumpulan data tentang geneologis kemiskinan, keberadaan dan keberfungsian ideologi nyegara gunungdalam mengatasi kemiskinan sosiokultural dilakukan dengan observasi, wawancara, dan studi pustaka. analisis data menggunakan analisis kritis deskreptif kualitatif.

\section{HASIL DAN PEMBAHASAN}

Penduduk Kabupaten Buleleng pada tahun 2010 berjumlah 662.920, yang bermatapencaharian utama sebagai nelayan laut sebanyak 7.297 orang, pengolah ikan sebanyak 815 orang, pembudidaya ikan sebanyak 786 orang. Masyarakat nelayan di kawasan pesisir Kabupaten Buleleng pada umumnya hidup dalam kemiskinan. Hal ini dapat dilihat dari terbatasnya modal finansial yang dimilikinya. Gambaran kemiskinan masyarakat nelayan dapat dilihat dari kondisi pemukiman, fasilitas rumah tangga yang dinilikinya, tingkat pendidikan dan penguasaan teknologi kemaritiman.

$\mathrm{Di}$ lihat dari segi pemukiman, perumahan masyarakat nelayan umumnya dibangun pada tanah negara di kawasan pesisir. Bangunan perumahannya sangat sederhana dan semi permanen, yang mempergunakan kerangka kayu/bambu dan berdindingkan bedeg atau batako dengan atap seng atau daun kelapa. Fasilitas rumah tangga umumnya sangat terbatas. Berkenaan dengan sangat sederhananya kondisi perumahan masyarakat nelayan, maka istilah penyebutan untuk rumah yang dimilikinya disebut dengan istilah kubu.

Kemiskinan yang dimiliki oleh masyarakat nelayan juga tergambarkan dari rendahnya tingkat pendidikan yang dimilikinya. Mereka umumnya hanya mengenyam pendidikan dasar. Terbatasnya tingkat pendidikan yang dimilikinya tidak hanya disebabkan oleh rendahnya kesadaran akan pentingnya pendidikan, tetapi cenderung disebabkan oleh keterbatasan kemampuan pembiayaan. Keterbatasan kemampuan ekonomi keluarga menyebabkan mereka lebih diposisikan sebagai bagian dari unit produksi untuk meningkatkan pendapatan keluarga. Artinya anak-anak dalam keluarga miskin lebih diposisikan sebagai sumber daya ekonomi keluarga dari pada sebagai sumber daya manusia yang harus ditingkatkan kualitasnya melalui proses pendidikan formal. Kondisi ini dipacu juga oleh pembiayaan pendidikan formal yang relatife cukup tinggi.

Keterbatasan modal finansial tentu saja berimplikasi pada keterbatasan pemilikan teknologi kelautan, karena setiap komponen dari teknologi kelautan diperoleh melalui mekanisme pasar pada kelembagaan pasar, baik pada pasar tradisional maupun pada pasar modern. Keterbatasan pengusaan teknologi tentu berimplikasi pada keterbatasan masyarakat nelayan memanfaatkan berbagai potensi pesisir dan laut. Kondisi kemiskinan masyarakat nelayan semacam inilah oleh Chamber digambarkan bagaikan cengkaraman gurita kemiskinan (1993). Namun dengan segala keterbatasannya, mereka terus berusaha memenuhi kebutuhan hidupnya melalui aktivitas nelayan, misalnya dengan kerja bagi hasil dengan nelayan lainnya.

Hal itu dilakukan sebagi perwujudan kesadarannya terhadap ideologi nyegara gunung. Keberadaan ideologi nyegara gunung tersebut sangat disadari oleh masyarakat Buleleng. Hal ini terlihat dari dikenalnya ungkapan nyegara gunung oleh masyarakat setempat. Ungkapan nyegara gunung yang tidak saja dimaknai sebagai ruang magis religius, tetapi juga merupakan suatu konstruksi kultural yang mengandung kesadaran akan keberadaan dari ruang hidup. Kesadaran nyegara gunung sebagai ruang hidup dapat disimak dari ungkapan masyarakat pesisir Buleleng yang menyatakan bahwa uma abiane di pasihe.

Kesadaran itu terrefleksikan dari adanya berbagai kegiatan produktif yang dilakukan baik di daerah pegunungan maupun di daerah pesisir. Di daerah 
pegunungan/ daratan masyarakat Buleleng mengembangkan berbagai aktivitas pertanian lahan basah dan/atau lahan kering. Di samping masyarakat setempat juga mengembangkan berbagai usaha peternakan. Sedangkan di daerah pesisir masyarakat setempat juga mengembangkan berbagai usaha produktif seperti pembuatan garam, pertambakan, dan penangkapan ikan.

Di kawasan ini telah berdiri berbagai sarana dan prasarana yang menunjang aktivitas kepariwisataan. Terjadinya perubahan tata guna tanah/alih fungsi lahan semacam itu tidak saja mengakibatkan semakin tergusurnya para petani dari aktivitas sosial ekonomi dan sosial religiusnya, tetapi juga berakibat terhadap kehidupan nelayan. Pembangunan sarana dan perasarana wisata seperti itu mengakibatkan keterhimpitan ruang hidup masyarakat nelayan. Sehingga ada di antara mereka yang mengalihkan usahanya ke sektor pariowisata misalnya sebagai pedagang acung, sebagai tukang pijat, sebagai pengantar tamu dalam wisata tirta di laut, atau sebagai pedagang cindramata. Hal itu dilakukan untuk mengatasi keterhimpitan kehidupan ekonominya.

Kondisi sosial ekonomi masyarakat nelayan seperti itu kalau tidak diberdayakan secara optimal akan menjadi tatangan yang cukup berarti bagi upaya pelestarian lingkungan, termasuk pengembangan terumbu karang. Namun, kalau dikelola dan diberdayakan dengan baik hal itu akan menjadi kekuatan yang cukup berarti baik dalam proses peningkatan kesejahteraan masyarakat nelayan maupun dalam proses pelestarian lingkungan. Sehubungan dengan hal itu, pelestarian lingkungan harus dapat memberi manfaat langsung maupun tidak langsung terhadap masyarakat pesisir. Hal ini sejalan dengan moto pelestarian lingkungan yang menyatakan karang lestari nelayan sejahtera. Sebagaimana yang dilakukan dalam pengembangan terumbu karang di kawasan pesisir dan laut Desa Pemuteran, Pemaron, dan Les. Kelestarian lingkungan pesisir tidak saja memberikan peningkatan kualitas ekosistem tetapi juga akan memberikan peluang bagi pengembangan ruang hidup baru bagi masyarakat pesisir, yaitu pengembangan wisata bahari, sebagaimana dikembangkan pada beberapa kawasan pesisir di Bali Utara. Pengembangan wisata bahari tentu akan memberikan peluang bagi masyarakat pesisir untuk mendeversifikasi usahanya.

Pemberdayaan dan diversifikasi usaha merupakan suatu altrnatif dalam mengatasi kemiskinan masyarakat pesisir. $\mathrm{Hal}$ itu sejalan dengan keberadaan kemiskinan yang disebabkan oleh faktor sosiokultural dan struktural. Sebagaimana dikemukakan oleh pakar kemiskinan yang menyatakan ada dua aliran besar yang melihat faktor-faktor penyebab terjadinya kemiskinan. Pertama, aliran modernisasi yang selalu menganggap terjadinya kemiskinan disebabkan oleh faktor internal masyarakat pesisir. Dalam aliran ini, kemiskinan nelayan terjadi sebagai akibat faktor budaya (etos, kemalasan) keterbatasan modal dan teknologi, keterbatasan manajemen, serta kondisi sumber daya alam. Umumnya, kemiskinan jenis ini disebut kemiskinan sosiokultural dan alamiah. Oleh karena itu, aliran ini selalu sarat dengan proposal modernisasi nelayan. Sudah sepatutnya nelayan mengubah budayanya, meningkatkan kapasitas teknologinya, dan memperbaiki sistem usahanya. Kedua, aliran struktural yang selalu menganggap faktor eksternal yang menyebabkan kemiskinan nelayan. Jadi, menurut aliran ini kemiskinan nelayan bukan karena budaya atau keterbatasan modal, melaikan karena faktor eksternal yang menghambat proses mobilitas vertikal masyarakat nelayan. Faktor eksternal itu berjenjang, pada tingkat mikrodesa maupun makrostruktural. Pada tingkat mikrodesa, masih ditemukan sejumlah pola hubungan patron-klien yang bersifat asimetris, yaitu suatu pola hubungan transfer surplus dari nelayan ke patron. Sementara itu, pada tingkat makrostruktural, belum ada 
dukungan politik terhadap pembangunan kelautan dan perikanan sehingga sektor kelautan dan perikanan tidak mampu berkembang seperti sektor-sektor lainnya (Satria, 2002).

Berpijak dari hal itu, dapat dinyatakan bahwa fenomena kemiskinan yang dialami oleh anggota masyarakat pesisir, bukan merupakan suatu fenomena yang terjadi begitu saja, tetapi disebabkan oleh berbagai faktor baik faktor internal maupun faktor eksternal. Berdasarkan kajian terhadap beberapa anggota masyarakat pesisir mengemuka berbagai fenomena yang cukup menarik. Dalam perspektif geneologis terhadap kemiskinan yang dialaminya dapat dinyatakan bahwa kemiskinan yang dialami oleh beberapa anggota masyarakat pesisir itu disebabkan oleh faktor internal. Hal ini dapat dilihat dari adanya kemalasan/ rendahnya etos kerja yang dimilikinya. Fenomena ini bila dikaitkan dengan pandangan David McClelland tentang the need for achievement, konsep ini disingkat dengan sebuah symbol, yakni: $n$-Ach. Kemalasan merupakan konskuwensi dari rendahnya dorongan berprestasi yang dimiliki anggota masyarakat nelayan. Rendahnya dorongan berprestasi memang akan memengaruhi tingkat produktifitas kerja. Rendahnya dorongan berprestasi pada anggota masyarakat pesisir terkait dengan orientasi nilai tentang hakekat waktu dari masyarakat pesisir, yang hanya berorientasi ke masa kini, dan orientasi nilai tentang hakikat kerja hanya untuk sesuap nasi, cukup untuk makan. Orientasi semacam ini oleh Koentjaraningrat sebagai refleksi dari mentalitas petani yang cepat puas dan kurang berorientasi ke masa depan.

Fenomena kemalasan inilah pada masa kolonial yang lebih jauh dikonstroksi oleh kaum kapitalisme ke dalam mitos pribumi malas, sebagaimana diungkapkan oleh Alatas dalam bukunya Mitos Pribumi Malas (1988). Dalam perwujudan emperis historis, ideologi kolonial memanfaatkan gagasan tentang pribumi yang malas untuk membenarkan praktek-praktek penindasan dan ketidakadilan dalam mobilisasi tenaga kerja. Pengkonstruksian semacam ini juga dapat terjadi dalam masyarakat modernis yang kapitalis, dengan menyatakan masyarakat pesisir pemalas. Pengkonstrusian mitos masyarkat pesisir malas bisa jadi memang merupakan penggambaran atas kenyataan emperis yang ada pada masyarakat pesisir. Namun, bisa juga sebagai sebuah proses pengkonstruksian teks guna menyelubungi kepentingan dari masyarakat politik/ penguasa atas kegagalannya dalam memperbaiki taraf hidup masyarakat pesisir. Atau paling tidak pengkonstruksian mitos masyarkat pesisir malas merupakan suatu upaya sistematis untuk memuluskan proposal pemerintah dalam melaksanakan modernisasi kemaritiman.

Modernisasi pada masyarakat pesisir tentu bagi kalangan pendukung paradigm modernis merupakan suatu keharusan dalam mengatasi keterbelakangan yang dialami oleh masyarakt pesisir. Akan tetapi bila dikaji lebih dalam, ternyata modernisasi pada masyarakat pesisir justru menimbulkan masalah baru, karena modernisasi sulit dijangkau oleh masyarakat yang mengalami keterhimpitan kehidupan ekonomi. Modernisasi hanya menguntungkan bagi masyarakat peisisr yang memiliki modal finansial yang memadai. Pemilikan modal finansial yang memadai pada umumnya berada pada anggota masyarakat pesisir yang kaya, atau para pengusaha. Kondisi seperti inilah yang membuka peluang bagi terjadinya perselingkuhan antara masyarakt politik dengan masyarakat ekonomi dalam memanfaatkan modal komunitas yang ada. Perselingkuhan semacam ini tentu akan memberikan kebermanfaatan bagi penguasa dan pengusaha, sedangkan masyarakat pesisir yang kurang mampu cenderung terpinggirkan dan kurang merasakan kebermanfaatan dari proses modernisasi. 
Sehubungan dengan hal itulah modernisasi mengakibatkan jurang yang semakin lebar antara yang kaya dan yang miskin, karena akan terjadi yang kaya semakin kaya yang miskin semakin miskin. Jeratan gurita kemiskinan akan semakin kuat akan dirasakan oleh masyarakat miskin karena hubungan patro-klien, pengusaha dengan pekerja, kaya dengan miskin yang bersifat asimetris, yaitu suatu pola hubungan transfer surplus dari nelayan miskin ke patron/pengusaha/ nelayan kaya. Ketimpangan yang semakin lebar dapat menjadi kekuatan yang cukup berarti bagi berkembangnya kecemburuan sosial, dan konflik sosial.

Berkurangnya modal finansial pada masyarakat pesisir juga sejalan dengan dinamika perjalanan sejarah dari kehidupan keluarganya, sebagai konskwensi dari adanya sistem waris dan terbelenggunya keluarga yang bersangkutan dari kemiskinan. Semakin kuatnya keterbelengguannya dari kemiskinan merupakan suatu pencerminan dari keterbatasan kemampuannya membebaskan diri dari cengkraman kemiskinan sebagai konskwensi dari keterbatasan kemampuan sumber daya manusia dalam memanfaatkan berbagai peluang yang ada dalam arena sosial/ruang hidup yang ada. Lebih-lebih dalam arena sosial cendrung terjadi perebutan berbagai sumber daya yang ada dalam ruang hidup. Dalam setiap persaingan tentu saja akan ada upaya-upaya dari pihak-pihak yang bersaing untuk selalu mengakumulasi modal, sehingga keterbatasan modal dan kemampuannya dalam mengakumulasikan modal menyebabkan masyarakat miskin terus terpinggirkan dan mengalami kekalahan dalam persaingan dalam memanfaatkan berbagai sumber daya yang ada. Fenomena seperti itu dialami oleh beberapa anggota masyarakat pesisir di berbagai wilayah di kawasan pesisir, sebagaimana diungkapkan oleh Putu Sudarmika (30) dari Desa Pemuteran yang menyatakan bahwa leluhur keluarganya dulu memiliki tanah tegalan yang cukup memadai namun sejalan dengan perjalanan sang waktu dan berkembangnya anggota keluarga tanah tersebut sekarang sudah tidak ada lagi. Kondisi memposisikan keberadaannya sebagai petani yang tidak bertanah atau petani miskin. Hal senada juga diungkapkan oleh Made Merta (42) nelayan yang berasal dari Desa Les yang menyatakan bahwa keberadaannya sebagai nelayan sebagai akibat dari tidak adanya lahan pertanian, sehingga sering dia ungkapkan pada keluarganya bahwa uma abiane ada di pesisir/sawah ladangnya ada di pesisir. Keterbelengguan anggota masyarakat pesisir dari kemiskinan juga disebabkan oleh kurang berpihaknyanya kebijakan pemerintah terhadap masyarakat pesisir. Hal ini dapat dilihat dari lebih berpihaknya pemerintah terhadap masyarakat petani sawah dan pengusaha pariwisata dibandingkan dengan masyarakat pesisir.

Kurang keberpihakakan pemerintah terhadap masyarakat pesisir juga dapat dilihat dari sangat sulitnya anggota masyarakat pesisir/nelayan memperoleh bantuan pijaman modal usaha dari kelembagaan keuangan formal seperti BRI. Keterbatasan peluang memanfaatkan kelembagaan keuangan formal mengakibatkan banyak di antara anggota masyarakat pesisir ada yang mengembangkan kredit sosial. Namun keterbatasan kemampuan kredit soial yang dikembangkannya mengharuskan mereka memanfaatkan kelembagaan bank swasta dan atau rentenir dalam mengatasi kesulitan finansial. Kenyataan ini tentu berkontribusi bagi semakin menguatnya jeratan gurita kemiskinan pada masyarakat pesisir, karena mereka terjerat dengan bunga uang yang cukup tinggi. Berpijak dari hal itu kemiskinan sosikultural yang dialami oleh masyarakat pesisir secara geneologi disebabkan oleh faktor kultural dan struktural.

Masyarakat pesisir di kawasan pesisir Bali Utara memandang laut sebagai suatu tatanan kosmis baik secara sekala 
maupun niskala. Laut sebagai tatanan kosmis secara sekala, oleh masyarakat setempat dipandang sebagai bagian dari alam yang dapat dijadikan sebagai suatu ruang hidup tempat berusaha/mengadu nasib. Pandangan masyarakat nelayan tentang laut sebagai ruang hidup dapat disimak dari ungkapan yang menyatakan uma abiane di pasihe. Ungkapan tersebut di satu sisi menyiratkan akan kekentalan budaya agraris yang dimiliki oleh masyarakat nelayan, sebagai konskwensi dari terjadinya pencekokan/ terkontaminasi oleh ideologi yang memandang tanah sawah dan tegalan sebagai suatu ekologi tempat mereka melakukan usaha produktif. Kekentalan terhadap budaya agraris tentu terkait dengan latar belakang kultur sosial ekonomi masyarakat nelayan, yang sebelumnya umumnya merupakan keluarga petani sawah atau bisa juga karena memang budaya agraris merupakan kultur besar dari masyarakat Bali.

Ungkapan tersebut disisi lain menyiratkan akan adanya kesadaran yang berkembang pada sebagian besar masyarakat pesisir, bahwa ruang hidup untuk mencari nafkah tidak hanya di sawah/uma dan tegalan/abian, tetapi juga di laut. Dengan demikian masyarakat nelayan telah mengembangkan suatu ideologi bipolarisasi sumber daya kehidupan. Hal ini sejalan dengan keberadaan ideologi nyegara - gunung, yang tidak hanya bernuansa sosialreligius tetapi juga bernuansa sosial ekonomi, kultural dan politik. Kesadaran akan laut sebagai ruang kosmis yang memiliki potensi yang dapat menunjang pemenuhan kebutuhan hidup masyarakat pesisir, telah mengembangkan kesadaran akan pentingnya pemeliharaan dan kelestarian ekosistem pesisir dan laut, sehingga dalam memanfaatkan lingkungan alam pesisir dan laut sebagai ruang hidup masyarakat menggunakan kearifankearifan tertentu.

Pemeliharaan kelestarian lingkungan pesisir dan laut tentu saja sangat tergantung dari intensifnya proses pengawasan. Dalam rangka itu masyarakat desa pakraman di kawasan pesisir mengembangkan sistem pengawasan yang berbasis masyarakat yang dikenal dengan nama pecalang segara dan Pokmaswas (Pokmaswas FKMPP, Pokmaswas Pecalang Segara Desa Pemuteran, Pokmaswas Kartika Desa Les, Pokmaswas Benteng Samudra). Di samping itu untuk mengintensifkan pengawasan terhadap lingkungan pesisir dan laut, Dinas Kelautan dan Perikanan Kabupaten Buleleng membentuk Tim Satgas Operasional Pengawasan Sumber Daya Perairan/Laut Kabupaten Buleleng yang anggotanya terdiri atas unsur Pol Airud, Polres, Kodim, Kejaksaan,TNI AL, Bagian Hukum Setda Buleleng, PPNS, dan Staf Dinas Kelautan dan Perikanan Kabupaten Buleleng. Keberadaan berbagai kelembagaan pengawasan kawasan pesisir dan laut tentu saja akan dapat berkontribusi bagi kelestarian lingkungan pesisir dan laut dengan berbagai ekosistemnya.

Di samping laut dipandang sebagai kesatuan kosmis yang bersifat sekala, laut juga dipandang sebagai kesatuan kosmis yang bersifat niskala. Dalam artian bahwa laut memiliki struktur kosmis dan kekuatan religius magis, yang dihuni oleh kekuatankekuatan gaib seperti: roh halus, tonya, dan dewa-dewi. Sehubungan dengan hal itu maka dalam proses pemanfaatan laut sebagai ruang hidup, dilakukannya dengan penuh kehati-hatian agar aktivitas yang dilakukannya tidak mengganggu keharmonisan ekosistem laut (alam laut beserta penghuninya baik sekala maupun niskala). Kesadaran masyarakat peisisr seperti itu memperkuat keyakinan masyarakat pesisir dalam setiap aktivitasnya untuk selalu menghaturkan persembahan terhadap penguasa laut, sehingga laut benar-benar dapat menjadi sumber tirta amertha (sumber kehidupan), dan pemeralinal penghapus segala penderitaan hidup umat manusia. Keberadaan segaragunung sebagai ruang hidup yang bersifat niskala atau yang bersifat magis religious, 
mendorong anggota masyarakat pesisir untuk selalu berpegang pada landasan spiritual.

Dalam konteks masyarakat Hindu ada ungkapan yang menyatakan bahwa alam ini merupakan kamandu bagi kehidupan umat manusia. Dengan demikian umat manusia dapat mengisap susu kehidupan darinya, melalui kerja yang berlandaskan dharma, karena tanpa bekerja peluang seperti itu tidak mungkin dapat dimanfaatkan. Bekerja merupakan kwajiban moral bagi setiap umat manusia, karena hakekat manusia adalah kerja. Bekerjalah dan bekerjalah karena tanpa bekerja jangankan untuk memelihara orang lain memelihara dirimu sendiri kamu tidak bisa (Bhagawad Gita Bab IV). Dengan demikian kesadara akan nyegara gunung, dan kesadaran terhadap kerja sebagai kwajiban moral merupakan etos bagi setiap umat manusia, termasuk masyarakat pesisir di Bali Utara. Etos semacam itu tentu menjadi kekuatan pendorong dalam proses kreativitas manusia dalam memanfaatkan ruang hidup nyegara gunung secara berkelanjutan. Dalam konteks inilah menjaga kelestarian ruang hidup nyegaragunung merupakan suatu keniscayaan.

Dalam setiap masyarakat ada tiga sendi masyarkat yang memiliki peran dan kepentingan tertentu. Masyarakat politik yang dalam hal ini Pemerintah Daerah Kabupaten Buleleng dengan berbagai jajarannya sampai ke tingkat desa dinas memainkan peranan penting dalam proses pengentasan kemiskinan pada masyarakat pesisir di Bali Utara. Upaya ke arah itu memang terbingkai dengan landasan kebijakan tri hita karana dengan keruangan yang bersifat nyegara gunung. Hal ini dapat disimak dari misi dan visi Renstra Kabupaten Buleleng. Implementasi dari visi dan misi itu dapat dilihat dari berbagai kebijakan yang telah dilakukannya pada masyarakat pesisir, seperti misalnya adanya pembinaan terhadap masyarakat pesisir dalam berbagai usaha produktif. Selama ini masyarakat pesisir di Kabupaten Buleleng melalui Dinas Perikanan dan Kelautan Kabupaten Buleleng telah mengembangkan berbagai program seperti LEPM3 pada tahun 2001.

Program ini memberikan pendampingan dana, dan manajemant organisasi. Sasaran program ini adalah nelayan penangkap ikan, pedagang ikan, dan pengolah ikan. Masing-masing kelompok tersebut diberikan bantuan dana bergulir sekitar Rp. 25.000.000,- sampai Rp. 50.000.000,-. Guna keberlangsungan dari program ini kemudian dibentuk Koprasi LEPM3. Program lain yang tidak kalah pentingnya dalam mengentaskan kemiskinan sosikultural pada masyarakat pesisir adalah memberikan pelatihanpelatihan penangkapan dan pengolahan ikan. Pelatihan semacam ini dimaksudkan untuk mengembangkan diversifikasi usaha pada masyarakat pesisir. Upaya lain yang dilakukan oleh masyarakat politik adalam pengembangan pelabuhan ikan di Desa Sangsit. Bantuan-bantuan yang diberikan oleh pemerintah daerah berbasiskan kelompok usaha. Di samping itu, pemerintah daerah juga mengembangkan berbagai usaha garam rakyat yang ada di kawasan pesisir Bali Utara, seperti di Desa Pejarakan dan Desa Les. Upaya lain yang tidak kalah pentingnya dilakukan oleh pemerintah daerah setempat adalah dengan mengembangkan pasilitas pendidikan. Pengembangan pasilitas pendidikan memeiliki peranan dalam mendisiplinkan, mengkontruk sumber daya manusia sehingga mampu memanfaatkan berbagai peluang yang ada di ruang hidup masyarakat sekitar.

Di samping masyarakat politik, masyarakat ekonomi juga ikut berperanan dalam mengatasi masalah kemiskinan sosiokultural pada masyarakat pesisir di Bali Utara. Hal ini dapat dilihat dari upaya masyarakat ekonomi dalam hal ini para pengusaha pariwisata dan kosmetika membantu masyarakat pesisir. Pengusaha pariwisata di Desa Pemuteran mengembangkan program pembinaan 
terhadap anak-anak dari keluarga masyarakat pesisir, seperti yang dilakukan oleh Pengusaha Hotel Ganesha menjadi bapak angkat dari Yayasan Anak Pemuteran. Pengusaha Hotel Kubuku menjadi bapak angkat/ donator tetap dari Yayasan Putera Sesana. Upaya lain yang dilakukan oleh para pengusaha pariwisata adalah menyerap tenaga kerja dari masyarakat setempat untuk bekerja pada unit-unit usaha yang dikembangkannya.Masyarakat ekonomi yang lainnya adalah pengusaha kosmetika CV.Graha Palimanan yang bekerja sama dengan Kelompok Nelayan Mina Bhakti Swansari. Pengusaha kosmitika mengupayakan pembudidayaan terumbu karang untuk kepentingan bahan baku kosmitika.

Masyarakat sipil juga ikut berperanan dalam membantu mengatasi masalah kemiskinan sosiokultural. Hal ini dapat dilihat dari keterlibatan beberapa LSM seperti LSM Lini, Bahtera Nusantara, dan Yayayasan Karang Lestari. LSM tersebut memeliki peranan dalam pemberdayan masyarakat pesisir dan lingkungan sekitarnya. Upaya tersebut tidak saja memperluas wawasan dari anggota masyarakat pesisir di Bali Utara tetapi juga memberikan kekuatan sehingga lebih mampu dalam bersaing memperebutkan berbagai modal sumber daya yang ada. Berpijak dari kenyataan tersebut maka dapat dinyatakan bahwa berbagai kelompok masyarakat telah berperanan dalam mengatasi kemiskinan cultural pada masyarakat pesisir. Upaya tersebut telah mampu membantu masyarakat miskin di wilayah pesisir Bali Utara dalam mengatasi jeratan kemiskinan. Hal ini terbukti dari adanya peningkatan tarap hidup masyarakat pesisir, sebagaimana diungkapkan oleh $\mathrm{Pt}$ Sudarmika (30), I Ketut Sekar (43), I Ketut Widiana (32), Made Gunaksa (32), Made Merta (44), Ketut Sarka (60) Gde Mangku (57), Nyoman Kepang (52). Terjadinya peningkatan kehidupan masyarakat pesisir tersebut dapat dilihat dari pemilikan rumah yang semi permanen, pasilitas rumah tangga seperti TV, sepeda motor, dan pemilikan unit usaha penangkapan ikan yang cukup memadai.

\section{SIMPULAN}

Berdasarkan uraian pada bagian penyajian hasil dan pembahasan dapat dikemukakan simpulan kajian ini sebagai berikut:

(1) Kemiskinan sosiokultural masyarakat di Bali Utara dapat dilihat dari lingkungan pemukiman masyarakat pesisir yang berada di sekitar pantai pada umumnya menempati tanah Negara dan dengan kondisi bangunan yang sangat sederhana. Kemiskinan sosiokultural yang dimilikinya juga tercermin oleh tingkat pendidikan dan penguasan teknologi kebaharian yang masih terbatas, kondisi ini tentu saja juga terkait dengan keterbatasan modal financial yang dimiliki oleh masyarakat pesisir. (2) Terjadinya kemiskinan sosiokultural pada masyarakat pesisir secara geneologi disebabkan oleh keterbatasan modal finansial yang dimiliki dan kebijakan-kebijakan pembangunan yang kurang berpihak pada masyarakat pesisir yang mengalami jeratan gurita kemiskinan. (3) Ideologi nyegara gunung oleh masyarakat pesisir dimaknai sebagai aktivitas magis religius dan sebagai ruang hidup. Dalam memanfaatkan ruang hidup di landasi kesadaran terhadap kerja sebagai kwajiban moral. Hal itu merupakan etos yang menjadi kekuatan pendorong dalam proses kreativitas manusia dalam memanfaatkan ruang hidup nyegara gunung secara berkelanjutan dalam mengatasi kemiskianan masyarakat pesisir. Dalam konteks inilah menjaga kelestarian ruang hidup nyegara-gunung merupakan suatu keniscayaan. (4) Untuk mengatasi kemiskinan sosiokultural masyarakat pesisir mengembangkan berbagai aktivitas sosial ekonomi yang dilandasi dengan kesadarannya terhadap kebenaran ideologi nyegara gunung, dan menjadikan laut sebagai ruang hidup yang menjanjikan. Di samping itu masyarakat pesisir juga 
mengembangkan berbagai diversifikasi usaha sebagai bentuk adaptasinya dalam mengatasi kemiskinan sosiokultural yang ada. Dalam mengatasi kemiskinan sosiokultural yang dihadapi oleh masyarakat pesisir, peranan masyarakat politik, ekonomi dan sipil sangat berarti, baik dalam bentuk pendampingan modal maupun pembinaan terhadap masyarakat pesisir. Sehingga masyarakat pesisir mampu mengurangi jeratan kemiskinan, bahkan ada diantara anggota masyarakat pesisir yang mengalami peningkatan kesejahteraan hidup dan mengalami mobilitas vertical maupun horizontal.

Mencermati realitas kemiskinan sosikultural pada masyarakat pesisir di Bali Utara yang sedang menghadapi berbagai tantangan baik dalam tataran arena, praksis, ranah, dan habitusnya, maka diperlukan adanya upaya-upaya kajian-kajian dalam rangka pengentasan dan peningkatan kualitas kehidupannya, upaya-uapaya yang dimaksud adalah sebagai berikut:

1. Adanya upaya identifikasi berbagai usaha diversifikasi usaha yang dikembangkan oleh masyarakat pesisir di Bali Utara untuk menemukenali usaha produktif yang mungkin memiliki prospek ke depan

2. Diperlukan upaya merevitalisasi dan mereinterpretasi makna dari nyegara gunung guna memaksimalkan keberfungsiannya bagi kehidupan masyarakat dan lingkungan alam sekitannya.

3. Diperlukan upaya-upaya yang bersifat sinergis secara berkelanjutan antara masyarakat ekonomi, politik dan sosial dalam mengatasi berbagai permasalahan sosial, ekonomi, kultural dan ekologis yang berkembang dalam masyarakat pesisir di Bali Utara.

\section{DAFTAR PUSTAKA}

Atmadja, Nengah Bawa, 1988, Dana dan Bhakti Sebagai Konsep Manunggaling
Kaula Gusti Dalam Perspektif Sejarah Bali, (Makalah), Singaraja: Universitas Panji Sakti.

1998, Komunitas Pantai Dalam Perspektif Sosiokultural, Makalah Seminar Nasional, Denpasar: Fakultas Sastra Universitas Udayana.

$$
\text { 2006, Bali Pada Era }
$$

Globalisasi, Singaraja: IKIP N Singaraja

2006, Pemulihan Krisis Kebangsaan dan Multikulturalisme dalam Perspektif Kajian Budaya, makalah, Singaraja: Undiksha.

BaumGarther,M.P, 1994, Sosial Control From Bellow, dalam Donald Black (ed), Toward a General Theory of Sosial Control, Halaman 303-339, Orlando: Academic.

Capra, Fritjoe, 1997, Titik Balik Perdaban Sains Masyarakat dan Kebangkitan Kebudayaan, Yogyakarta: Yayasan Bentang Budaya.

Chambers, Robert, 1993, Pembangunan Desa Mulai Dari Belakang, Jakarta: LP3ES.

Dove, Michael R, 1985, Pendahuluan, dalam Michael R. Dove (ed), Peranan Kebudayaan Tradisional Indonesia, Halaman xv, Jakarta: Yayasan Obor Indonesia.

1994, Kata Pengantar, dalam Paulus Florus (ed), Kebudayaan Dayak Aktualisasi dan Transformasi, Halaman xxiii - xiii, Jakarta: Grasindo.

Fakih,Mansour,2003,Runtuhnya Teori Pembangunan dan Globalisasi,Yogyakarta: Imssit Press

Geertz, C, 1976, Involusi Pertanian Proses Perubahan Ekologi di Indonesia, Jakarta: Bhratara. 
Hasbullah, Jousairi,2006, Sosial Capital, Menuju Keunggulan Budaya Manusia Indonesia, Jakarta: MR-United Press.

Korten, David C., 1993, Menuju Abad Ke 21: Tindakan Sukarela dan Agenda Global, Jakarta: Sinar Harapan.

Kusnadi, 1997, Diversifikasi Pekerjaan di Kalangan Nelayan, dalam Prisma, No.7/97, Jakarta: LP3ES.

1999, Redifinisi Kebijakan Pengelolaan Sumber Daya Laut Di Perairan Selat Madura, Perspektif dari Situbondo, Jawa Timur, Makalah, Denpasar: Universitas Udayana.

2002, Konflik Sosial Nelayan Kemiskinan dan Perubahan Sumber daya perikanan, Yogyakarta: LKiS 2003, Akar Kemiskinan Nelayan, Yogyakarta: LKiS.

Kusumaatmadja, Sarwono, 2000, Wisata Bahari Sebagai Andalan Pembangunan Nasional, Makalah, Denpasar: Universitas Udayana.
Mubyarto, Loekman Soetrisno, dan Michael Dove, 1984, Nelayan dan Kemiskinan Studi Ekonomi Antropologi di Dua Desa Pantai, Jakarta: Rajawali.

Mudana, I Wayan,.1998, Terhimpit Dibalik Lipatan Dolar ( Kajian Antropologi Terhadap Kehidupan Nelayan Pada Kawasan Pemukiman Wisata di Pantai Bali Utara), Singaraja: STKIP. 2001, Kredit Sosial dan Kredit Ekonomi pada Masyarakat Nelayan di Desa Kubutambahan, Tesis S2 Kajian Budaya, Denpasar: UNUD , 2003, Kekuatan Religius Magis Dalam Proses Eksploitasi Sumber Daya Kelautan Pada Masyarakat Nelayan di Bali Utara, Singaraja: IKIP Negeri Singaraja.

Scott, James C., 198I, Moral Ekonomi Petani Pergolakan dan Subsistensi di Asia Tenggara, Jakarta: LP3ES.

Susilo, Y Eko Budi.2003. Menuju Keselarasan Lingkungan. iMalang: Averroes Press. 